\title{
Effect of Crayfish Inclusion on the Chemical and Sensory Properties of Ogi Prepared from Maize, Millet and Sorghum
}

\author{
Sengev Iorfa Abraham*, Nwobi Ifeanyi, Sule Stephen \\ Department of Food Science and Technology, University of Agriculture, Makurdi, Nigeria \\ Email address: \\ sengev.abraham@uam.edu.ng (S. I. Abraham), Ifex2k4real02@gmail.com (N. Ifeanyi), stevsule@gmail.com (S. Stephen) \\ *Corresponding author
}

\section{To cite this article:}

Sengev Iorfa Abraham, Nwobi Ifeanyi, Sule Stephen. Effect of Crayfish Inclusion on the Chemical and Sensory Properties of Ogi Prepared from Maize, Millet and Sorghum. International Journal of Nutrition and Food Sciences. Vol. 5, No. 6, 2016, pp. 378-383. doi: $10.11648 /$ j.ijnfs.20160506.12

Received: July 3, 2016; Accepted: September 26, 2016; Published: October 18, 2016

\begin{abstract}
The effect of crayfish inclusion on the chemical and sensory properties of ogi prepared from maize, millet and sorghum was investigated. Blends were formulated based on a 13g/day protein RDA for toddlers as established by the Protein Advisory Group and were analysed for chemical and sensory attributes. All data were statistically analysed and significance difference was accepted at 5\% probability level. All samples met the recommended dietary allowance (RDA) for Ash $(<3 \mathrm{~g} /$ day $)$, fibre $(<5 \mathrm{~g} /$ day $)$, carbohydrate $(64 \mathrm{~g} /$ day) and protein $(13 \mathrm{~g} /$ day $)$. There was significant difference $(\mathrm{p}<0.05)$ among all samples in terms of Vitamin A and D contents with values ranging from 8.39 to $5.34 \mu \mathrm{g} / 100 \mathrm{~g}$ and 0.22 to $0.27 \mathrm{mg} / 100$, respectively. There was however no significant difference $(p>0.05)$ in vitamin B contents among the samples. The samples fell short of the RDA in terms of mineral composition. Anti-nutritional factors in the ogi samples were low, implying a high bioavailability of minerals with the exception of calcium as evident in the molars ratio calculated. Sensory scores revealed substantial overall acceptability of the samples. The quality of ogi samples were greatly affected by crayfish inclusion and hence could provide appreciable nutritional benefits for both infant and adults.
\end{abstract}

Keywords: Ogi, Vitamins, Chemical Properties, Anti-nutrients, Sorghum

\section{Introduction}

In many parts of the world and especially in Africa, cereals and their products are very well utilized as staple foods. They have been principal components of human diet for thousands of years [1]. They contribute significantly to the overall energy and protein intake in the areas of high consumption. A major fermented cereal product used as food for both infants and adults is $O g i$.

$O g i$ is a locally prepared semi-solid food from fermented cereals (maize, millet and sorghum) in many African countries including Nigeria [2]. It is highly energy dense and also a good lactose stimulant for nursing mothers. The traditional preparation of ogi involves the processes of steeping maize, millet or sorghum in water (1-2 days), followed by wet-milling, wet-sieving and fermentation for 2 3 days [3-4].

Malnutrition associated with reduced consumption of breast milk and over-consumption of high energy dense complementary foods such as ogi is an area requiring continuous intervention through fortification, supplementation, dietary diversification, nutrition education, etc which if not addressed especially during the crucial period of infancy, could lead to permanent negative impact on their health and quality of life. Poor feeding practices and short fall in food intake remain the most direct causes of malnutrition and ill health amongst children.

Crayfish (Procambarus clarkii) are fresh water crustaceans which in recent times have been receiving increasing research attention. They are excellent sources of micro nutrients and proteins which can impart nutritive value to foods.

Ogi generally has been implicated as contributing to the prevalence of kwashiorkor among infants [5] owing to its high energy density and reduced proteins. This has informed many research attempts to improve its nutritional value with plant and animal protein sources [6-9] in order to meet the 
Dietary Reference Intake (DRI) for infants [10].

The present study was aimed to elucidate the effect of crayfish inclusion on the quality of ogi prepared from maize, sorghum and millet.

\section{Materials and Methods}

\subsection{Sample Procurement}

Cereals (maize, millet and sorghum) and crayfish (Procambarus clarkii) were purchased from Gboko main market, Benue State, Nigeria.

\subsection{Sample Preparation.}

Ogi samples were prepared traditionally from maize, millet and sorghum following the method described by Odunfa [3]. Cereal grains were cleaned and then steeped in water for $48 \mathrm{~h}$. The steeped water was decanted and the grains wet-milled before sieving with muslin cloth. The pomace was then discarded and the suspension was allowed to sediment for $48 \mathrm{~h}$ during which fermentation occurred. The ogi collected was sundried, sieved and stored in airtight containers.

Crayfish was processed into powder as described by Iombor et al. [11]. The process involved cleaning, sun drying, milling and sieving to obtain fine powder, after which it was packaged in an air tight container subsequent to further usage.

\subsection{Blend Formulation}

Crayfish powder was incorporated into the respective cereal-based ogi samples through material balancing [12] based on the protein contents of the individual food materials to achieve a targeted $13 \%$ protein food as recommended by the Protein Advisory Group [13] for toddlers (Table 1).

\subsection{Determination of Proximate Composition}

Moisture, fat, protein ( $\% \mathrm{~N} \times 6.25)$, ash and crude fibre contents were determined according to standard methods of AOAC [14]. Carbohydrate content was calculated by difference as described by Ihekoronye and Ngoddy [15].

\subsection{Determination of Anti-nutritional Factors}

Phytate, oxalate, saponins, tannins and trypsin inhibitor contents in the crayfish-blended ogi samples were determined using a spectrophotometer (Spectro Sc 20, Labomed, Inc. USA) [16]

\subsection{Determination of Mineral Contents}

Mineral determination was carried out by acid digestion according to AOAC [14]. The ash obtained after incineration at $500^{\circ} \mathrm{C}$ was dissolved in aquaregia $(10 \mathrm{~mL}$ nitric acid $+30 \mathrm{~mL} \mathrm{HCl}$ ) solution and boiled for $30 \mathrm{~min}$. The mixture was transferred into a $250 \mathrm{~mL}$ volumetric flask and boiled again for $30 \mathrm{~min}$. The mixture was filtered into $100 \mathrm{~mL}$ volumetric flask and made up to the mark with distilled water. The mineral concentration was determined using the Atomic Absorption Spectrophotometer (Model: 6405 UV/VIS,
Jenway, UK).

\subsection{Determination of Vitamins}

Vitamin $\mathrm{A}, \mathrm{B}_{1}, \mathrm{~B}_{12}$ and $\mathrm{D}$ were evaluated using HPLC (Model: BLC-10/11, BUCK Scientific, USA) techniques as described by AOAC [14]. For each sample, 3.0g was mixed with $5 \mathrm{~mL}$ of $\mathrm{n}$-hexane and $20 \mathrm{~mL}$ of HPLC grade water. The mixture was homogenized at $12000 \mathrm{rpm}$ and centrifuged $(3500 \mathrm{x} \mathrm{g})$ for $30 \mathrm{~min}$. followed by sequential filtration through whatman No 1 filter paper and $0.45 \mu \mathrm{m}$ membrane. Then $15 \mu \mathrm{L}$ of the supernatant was injected into the HPLC equipped with a UV detector set at $254 \mathrm{~nm}$. The peaks of the vitamins in the samples were calculated in relation to the peaks of standard vitamins.

\subsection{Determination of Molar Ratio of Anti-nutrients to Minerals}

The molar ratio of anti-nutrients to minerals was obtained by dividing the mole of anti-nutrient with the mole of minerals [16]

\subsection{Sensory Evaluation}

Crayfish blended $O g i$ samples were processed into semisolids ready for consumption and served to a 15 -member panel comprising staff and students of the Department of Food Science and Technology, University of Agriculture, Makurdi, Benue State, Nigeria to evaluate attributes such as appearance, aroma, taste, mouth feel, and overall acceptability using a 9-point hedonic scale [17]

Table 1. Blend ratio for crayfish incorporated Ogi (\% dry weight).

\begin{tabular}{llll}
\hline Sample & A & B & C \\
\hline Maize ogi & 87.89 & - & - \\
Millet ogi & - & 87.67 & - \\
Sorghum ogi & - & - & 89.23 \\
Crayfish & 12.11 & 12.33 & 10.77 \\
\hline
\end{tabular}

\subsection{Statistical Analysis}

Data obtained was analysed using a one way of variance. Means were separated using Duncan's multiple range test and significance difference was accepted at $5 \%$ probability ( $p<$ $0.05)$.

\section{Results and Discussion}

\subsection{Effect of Crayfish Inclusion on the Proximate Composition of Ogi}

Results for effect of crayfish inclusion on the proximate composition of $O g i$ from maize, millet and sorghum are presented in Table 2. Significant differences $(p<0.05)$ were observed between all samples for moisture, crude fat, ash, protein and carbohydrate contents. The moisture content of the formulated ogi samples ranged from $10.84-12.05 \%$ and was highest with sorghum-based ogi. The moisture content of food gives an indication of its safety and microbial stability 
[18]. Crude fibre, ash, carbohydrate and protein contents of the ogi blends compared favourably with the FAO/WHO [19] recommended values of $<5 \%$ fibre, $<3 \%$ ash, $64 \%$ carbohydrate and $13 \%$ protein. The low fibre content of the samples would permit substantial consumption during complementary feeding, thereby providing a greater opportunity to meet the daily energy and other vital nutrient requirements for children. The fat contents of the blends were lower than the FAO/WHO [19] recommended value (10$24 \%$ ). This may be attributed to the effect of fermentation on the cereals. The results obtained in this study are comparable with findings of Ijarotimi and Keshinro [20].

\subsection{Effect of Crayfish Inclusion on Vitamins Content of Ogi}

Vitamin A content in all samples differed significantly $(\mathrm{p}<$ 0.05 ) with crayfish-blended maize ogi having the highest value of $8.39 \mu \mathrm{g} / 100 \mathrm{~g}$ and millet based ogi having the least value of $5.34 \mu \mathrm{g} / 100 \mathrm{~g}$ (Table 3 ). The vitamin A content of all samples fell short of the recommended dietary allowance (RDA) for children between the ages of $1-3(210 \mu \mathrm{g} /$ day $)$. This may be due to dilution effect from the cereal materials which are known to be deficient in vitamin A. Vitamin A is essential for improvement of vision and maintaining body tissues among many other functions [21]. There was no significant difference $(\mathrm{p}>0.05)$ between all samples in vitamin $\mathrm{B}_{1}$ content. The vitamin $\mathrm{B}_{1}$ content of all samples met the recommended dietary allowance for toddlers $(0.4 \mathrm{mg} /$ day $)$. Vitamin $\mathrm{B}_{1}$ (thiamin) is useful in the generation of energy from carbohydrates [22]. Vitamin $\mathrm{B}_{12}$ values of the ogi samples ranged from $0.50-0.54 \mathrm{mg} / 100 \mathrm{~g}$. Vitamin $B_{12}$ is required for cellular metabolism of macro nutrients. It is also fundamental in the synthesis of blood cells in bone marrow [23]. The vitamin $B_{12}$ content of all samples fell below the [RDA] of $0.7 \mathrm{mg} /$ day for toddlers as recommended by FAO/WHO [19].

Crayfish-blended sorghum ogi was highest in vitamin D content $(0.27 \mathrm{mg} / 100 \mathrm{~g})$ (Table 3$)$. Vitamin D content of all samples met the RDAof $0.01 \mathrm{mg} /$ day for toddlers. Vitamin D aids in the absorption of calcium and its deficiency results in bone diseases such as rickets. The values obtained are consistent with those obtained by Solomon [24] on Nutritive value of three potential cereals-legume based complementary foods.

Table 2. Effect of Crayfish Inclusion on the Proximate Composition of Ogi (\% dry basis).

\begin{tabular}{lllllll}
\hline Samples & Moisture & Crude Fat & Ash & Crude Fibre & CHO & Protein \\
\hline A & $11.16^{\mathrm{b}} \pm 0.02$ & $4.10^{\mathrm{b}} \pm 0.05$ & $2.80^{\mathrm{a}} \pm 0.10$ & $2.79^{\mathrm{b}} \pm 0.01$ & $78.18^{\mathrm{c}} \pm 0.01$ & $12.13^{\mathrm{b}} \pm 0.02$ \\
B & $10.84^{\mathrm{c}} \pm 0.10$ & $3.00^{\mathrm{c}} \pm 0.20$ & $2.62^{\mathrm{b}} \pm 0.03$ & $2.87^{\mathrm{a}} \pm 0.20$ & $78.64^{\mathrm{b}} \pm 0.10$ & $12.87^{\mathrm{a}} \pm 0.01$ \\
C & $12.05^{\mathrm{a}} \pm 0.03$ & $4.36^{\mathrm{a}} \pm 0.01$ & $2.44^{\mathrm{c}} \pm 0.07$ & $2.80^{\mathrm{b}} \pm 0.05$ & $79.34^{\mathrm{a}} \pm 0.01$ & $11.06^{\mathrm{c}} \pm 0.01$ \\
LSD & 0.01 & 0.01 & 0.01 & 0.01 & 0.02 & 0.01 \\
FAO/WHO & $<5$ & $10-25$ & $<3$ & $<5$ & 64 & 13 \\
\hline
\end{tabular}

Values are means \pm standard deviation of duplicate determinations.

Values in the column followed by the same superscript are not significantly different $(\mathrm{p}>0.05)$

LSD: Least Significant Difference

Table 3. Effect of Crayfish Inclusion on the Vitamin Content of Ogi.

\begin{tabular}{lllll}
\hline Samples & Vitamin A $(\boldsymbol{\mu g})$ & $\begin{array}{l}\text { Vitamin } B_{1} \\
(\mathbf{m g} / \mathbf{1 0 0 g})\end{array}$ & $\begin{array}{l}\text { Vitamin } B_{12} \\
(\mathbf{m g} / \mathbf{1 0 0 g})\end{array}$ & $\begin{array}{l}\text { Vitamin D } \\
(\mathbf{m g} / \mathbf{1 0 0 g})\end{array}$ \\
\hline $\mathrm{A}$ & $8.39^{\mathrm{a}} \pm 0.01$ & $0.57^{\mathrm{a}} \pm 0.10$ & $0.54^{\mathrm{a}} \pm 0.04$ & $0.22^{\mathrm{c}} \pm 0.01$ \\
$\mathrm{~B}$ & $5.34^{\mathrm{b}} \pm 0.20$ & $0.58^{\mathrm{a}} \pm 0.02$ & $0.50^{\mathrm{b}} \pm 0.10$ & $0.24^{\mathrm{b}} \pm 0.10$ \\
$\mathrm{C}$ & $6.32^{\mathrm{c}} \pm 0.01$ & $0.58^{\mathrm{a}} \pm 0.08$ & $0.53^{\mathrm{a}} \pm 0.30$ & $0.27^{\mathrm{a}} \pm 0.02$ \\
LSD & 0.01 & 0.01 & 0.01 & 0.01 \\
\hline
\end{tabular}

Values are means \pm standard deviation of duplicate determination. Values in the column followed by the same superscript are not significantly different $(\mathrm{p}>0.05)$

\subsection{Effect of Crayfish Inclusion on the Mineral Content of Ogi}

Table 4 showed the effect of crayfish inclusion on the mineral composition of $O g i$ from maize, millet and sorghum. There was no significant difference $(p>0.05)$ in calcium content of the crayfish incorporated ogi samples from maize and sorghum as well as with millet and sorghum. Difference, however, existed between crayfish-blended maize and millet ogi samples. Calcium forms a major component of bones and assists in teeth development. It also plays a role in blood coagulation [25]. Iodine content in all samples ranged from 0.27 to $0.28 \mathrm{mg} / 100 \mathrm{~g}$ with no significant difference, although crayfish-blended maize ogi was highest. Iodine is required as a mandatory structural and functional element of thyroid hormones [26]. Its deficiency results in goitre. Iron content was significantly different in all the samples and was lowest with crayfish-blended millet ogi. Iron is essential for normal functioning of central nervous system and in the oxidation of carbohydrates, protein and fats [27]. Iron is also necessary for the formation of haemoglobin and also plays an important role in oxygen transfer in human body [28].

Although magnesium content was lowest with crayfishblended millet, values were not significantly different. Magnesium is required for normal functioning of the muscle and nervous systems, helps in supporting a healthy immune system, keeps bone strong and helps in regulating blood sugar levels, thereby promoting normal blood pressure [29].

Values for manganese ranged from $0.15-0.19 \mathrm{mg} / 100 \mathrm{~g}$ with crayfish-blended maize ogi significantly $(\mathrm{p}<0.05)$ different from those of millet and sorghum ogi. This variation may be due to the respective composition in parent cereal material. Manganese helps in developing healthy bone structure and creation of essential enzymes for building bones. It also acts as a co-enzyme to assist metabolic activity in the human body. Other benefits include the formation of connective tissues, absorption of calcium, proper functioning of the thyroid gland, regulation of blood sugar level and 
metabolism of fats and carbohydrates [27].

Phosphorous and Zinc contents ranged from 0.86 to $0.89 \mathrm{mg} / 100 \mathrm{~g}$ and 1.28 to $1.34 \mathrm{mg} / 100 \mathrm{~g}$ respectively. In a similar manner, phosphorus and zinc contents of crayfishblended millet ogi were significantly different from those from maize and sorghum based ogi. Zinc is an essential trace element and plays an important role in various cell processes including normal growth, brain development, behavioural response, bone formation and wound healing [30].

Mineral composition values fell below the FAO/WHO [19] recommended values for toddlers. This could be attributed in part to the low amount of crayfish added in the blend and also to the low mineral contents of the cereals.

Table 4. Effect of Crayfish Inclusion on the Mineral Content of Ogi ( $\mathrm{mg} / \mathrm{lo0g}$ ).

\begin{tabular}{llllllll}
\hline Samples & Calcium & Iodine & Iron & Magnesium & Manganese & Phosphorus & Zinc \\
\hline A & $0.14^{\mathrm{a}} \pm 0.11$ & $0.28^{\mathrm{a}} \pm 0.03$ & $1.43^{\mathrm{a}} \pm 0.01$ & $0.13^{\mathrm{a}} \pm 0.07$ & $0.15^{\mathrm{b}} \pm 0.01$ & $0.89^{\mathrm{a}} \pm 0.01$ & $1.34^{\mathrm{a}} \pm 0.02$ \\
$\mathrm{~B}$ & $0.12^{\mathrm{b}} \pm 0.05$ & $0.27^{\mathrm{a}} \pm 0.10$ & $1.33^{\mathrm{c}} \pm 0.11$ & $0.12^{\mathrm{a}} \pm 0.03$ & $0.19^{\mathrm{a}} \pm 0.20$ & $0.86^{\mathrm{b}} \pm 0.02$ & $1.28^{\mathrm{b}} \pm 0.10$ \\
$\mathrm{C}$ & $0.13^{\mathrm{ab}} \pm 0.10$ & $0.27^{\mathrm{a}} \pm 0.02$ & $1.41^{\mathrm{b}} \pm 0.01$ & $0.13^{\mathrm{a}} \pm 0.05$ & $0.18^{\mathrm{a}} \pm 0.13$ & $0.89^{\mathrm{a}} \pm 0.01$ & $1.33^{\mathrm{a}} \pm 0.04$ \\
LSD & 0.01 & 0.01 & 0.01 & 0.01 & 0.01 & 0.03 & 0.01 \\
FAO/WHO & 500 & 65 & 16 & 76 & 32 & 456 & 3.2 \\
\hline
\end{tabular}

Values are means \pm standard deviation of duplicate determinations.

Values in the column followed by the same superscript are not significantly different $(\mathrm{p}>0.05)$

LSD: Least Significant Difference

\subsection{Effect of Crayfish Inclusion on Anti-nutritional Factors in Ogi}

Significant differences $(\mathrm{p}<0.05)$ in oxalate concentration between crayfish-blended ogi samples were recorded (Table 5). Maize based ogi was highest $(1.24 \mathrm{mg} / 100 \mathrm{~g})$ in oxalate concentration probably due to concentration in parent cereal. Similar results were recorded by Ijarotimi et al. [20]. Oxalates bind calcium present in food, thus rendering it unavailable for body utilization. They also precipitate protein around body tissues [31]. There was no significant difference $(p>0.05)$ in the phytate content between all the samples with values ranging between 1.37 to $1.39 \mathrm{mg} / 100 \mathrm{~g}$. Phytates have been reported to form indigestible complexes with minerals, thereby decreasing the bioavailability of these minerals [32]. Saponin and tannin concentrations of the samples varied significantly ( $\mathrm{p}<0.05)$ with values ranging from $0.70 \mathrm{mg} / 100 \mathrm{~g}$ to $0.79 \mathrm{mg} / 100 \mathrm{~g}$ and $116.8 \mathrm{mg} / 100 \mathrm{~g}$ to $121.0 \mathrm{mg} / 100 \mathrm{~g}$ respectively. Growth stagnation has been associated with high levels of tannins in foods [33]. No significant difference was observed for trypsin inhibitor contents between the crayfish incorporated ogi samples from maize and millet. Values were higher than those reported by Folake et al. [34] using rice-based masa, soybean and crayfish.

\subsection{Molar Ratios of Anti-nutrients to Minerals in Crayfish-Blended Ogi}

The molar ratios of calcium, zinc, iron, oxalate, and phytate were calculated as an index of bioavailability of dietary minerals (Table 6).

\subsubsection{Phytate/Calcium}

The Phytate: Calcium molar ratio has been proposed as an indicator of $\mathrm{Ca}$ bioavailability [35]. Phytic acid has been identified as a major contributor to decreasing calcium bioavailability. Ratios obtained in this study were higher in all samples than the critical toxicity value $(<0.24)$, indicating inhibitory action of phytates on calcium.

\subsubsection{Phytate/Iron}

Phytate: Iron molar ratios greater than 0.15 are indicative of poor iron bioavailability [36]. Results from this study in terms of phytate: iron molar ratios of all the samples were less than the critical value, implying a likelihood of good iron absorption when ingested.

\subsubsection{Phytate/Zinc}

The importance of foodstuffs as a source of dietary zinc depends on both the total zinc content and the level of other constituents in the diet that affect zinc bioavailability. Values for phytate: zinc molar ratio were lower than the critical molar ratios of Phy: $\mathrm{Zn}$, indicating good availability of zinc. Phytate: zinc molar ratio is considered a better indicator of zinc bioavailability than total dietary phytate levels alone [37].

\subsubsection{Oxalate/Calcium}

The importance of oxalate contents of an individual plant product in limiting total dietary calcium availability is of significance only when the ratio of Oxalate: calcium is greater than 1 [38]. Bioavailability of calcium from the study was acceptable. Values were lower scores than the critical value of 1. Oxalic acid and its salts can have deleterious effects on human nutrition and health, particularly by decreasing calcium absorption and aiding the formation of kidney stones [39].

\subsection{5. (Phytate) (Calcium)/(Zinc) Molar Ratios}

The potential effect of calcium on zinc absorption in the presence of high phytate intakes has led to the suggestion that the (Phy) $(\mathrm{Ca}) /(\mathrm{Zn})$ millimolar ratio may be a better index of zinc bioavailability than the [Phy]/ [Zn] molar ratio alone. In this study, the values of $(\mathrm{Ca})(\mathrm{Phy}) /(\mathrm{Zn})$ millimolar ratios of all the samples were lower than the critical level (0.50). 
Table 5. Effect of Crayfish Inclusion on the Anti-nutritional Composition of Ogi $(100 \mathrm{~g} / \mathrm{mg})$.

\begin{tabular}{|c|c|c|c|c|c|}
\hline Samples & Oxalate & Phytate & Saponins & Tannins & Trypsin Inhibitor \\
\hline A & $1.24^{\mathrm{a}} \pm 0.120$ & $1.39^{\mathrm{a}} \pm 0.01$ & $0.79^{\mathrm{a}} \pm 0.02$ & $120.40^{\mathrm{b}} \pm 0.03$ & $0.81^{\mathrm{a}} \pm 0.06$ \\
\hline B & $1.07^{c} \pm 0.08$ & $1.37^{\mathrm{a}} \pm 0.10$ & $0.76^{\mathrm{b}} \pm 0.10$ & $116.80^{c} \pm 0.01$ & $0.72^{b} \pm 0.01$ \\
\hline $\mathrm{C}$ & $1.13^{\mathrm{b}} \pm 0.20$ & $1.33^{\mathrm{a}} \pm 0.06$ & $0.70^{c} \pm 0.03$ & $121.00^{\mathrm{a}} \pm 0.01$ & $0.73^{b} \pm 0.03$ \\
\hline LSD & 0.01 & 0.07 & 0.01 & 0.01 & 0.01 \\
\hline
\end{tabular}

Values are means \pm standard deviation of duplicate determinations.

Values in the column followed by the same superscript are not significantly different $(p>0.05)$

LSD: Least Significant Difference

Table 6. Molar Ratios (mol/kg) Anti nutrients to Minerals in Ogi.

\begin{tabular}{|c|c|c|c|c|c|}
\hline Samples & Phytate: Ca & Phytate: Fe & Phytate: Zn & Oxalate: Ca & (phytate x Ca): Zn \\
\hline A & 0.602 & 0.102 & 0.082 & 4.025 & 0.004 \\
\hline B & 0.692 & 0.105 & 0.087 & 4.052 & 0.003 \\
\hline $\mathrm{C}$ & 0.620 & 0.098 & 0.080 & 3.950 & 0.003 \\
\hline Critical value & 0.24 & 0.15 & 10.00 & 1.00 & 0.50 \\
\hline
\end{tabular}

\subsection{Effect of Crayfish Inclusion on the Sensory Characteristics of Ogi}

While significant differences $(p<0.05)$ were observed between samples for appearance and mouth feel, there was no difference in terms of aroma, taste and general acceptability (Table 7). The similarities in aroma, taste and general acceptability could be attributed to the contribution of crayfish. Crayfish has a characteristic aroma and taste which it impacts on foods. Differences in appearance and mouth feel could be due to the characteristic parent cereal material.

Table 7. Effect of Crayfish Inclusion on the Sensory attributes of Ogi.

\begin{tabular}{llllll}
\hline Samples & Appearance & Aroma & Taste & $\begin{array}{l}\text { Mouth } \\
\text { feel }\end{array}$ & $\begin{array}{l}\text { General } \\
\text { Acceptability }\end{array}$ \\
\hline A & $7.75^{\mathrm{a}}$ & $7.50^{\mathrm{a}}$ & $7.05^{\mathrm{a}}$ & $7.05^{\mathrm{a}}$ & $7.50^{\mathrm{a}}$ \\
$\mathrm{B}$ & $6.65^{\mathrm{b}}$ & $7.10^{\mathrm{a}}$ & $6.85^{\mathrm{a}}$ & $6.60^{\mathrm{b}}$ & $6.85^{\mathrm{a}}$ \\
$\mathrm{C}$ & $6.70^{\mathrm{b}}$ & $7.10^{\mathrm{a}}$ & $7.75^{\mathrm{a}}$ & $7.75^{\mathrm{ab}}$ & $6.80^{\mathrm{a}}$ \\
LSD & 0.77 & 0.89 & 0.89 & 0.77 & 0.84 \\
\hline
\end{tabular}

Values in the column followed by the same superscript are not significantly different $(\mathrm{p}>0.05)$

\section{Conclusion}

Crayfish inclusion imparted positively on the nutritional value of ogi, making it a good source of nutrients for both weaning infant and adults. The anti-nutritional factors in the formulated $O g i$ samples were low, implying a high bioavailability of its mineral with the exception of calcium. The sensory data also revealed that all the formulated food samples were generally accepted.

\section{References}

[1] Awika, J. M., Piironen, V. And Bean, S. 2011. Advances in Cereal Science: Implications to Food Processing and Health Promotion, ACS Symposium Series, American Chemical Society, Washington DC. Pp 1-13.

[2] Afolayan, M. O., Afolayan, M. and Abuah, J. N. 2010. An Investigation into Sorghum Based Ogi (Ogi-Baba) Storage
Characteristics, Advanced Journal of Food Science and Technology, 2 (1): 72-78.

[3] Odunfa, S. A. 1985. African fermented foods: in Microbiology of Fermented Foods, Wood, B.J. (ed), vol 2, Elsevier Applied Science Publishers. London.

[4] Akinrele, I. A. 1970. Fermentation Studies on Sorghum During the Preparation of a Traditional African Starch-Cake Food. Journal of the Science of Food and Agriculture, 21: 619-625.

[5] Akanbi, C. T., Ade-Omowaye, B. I., Ojo, A. and Adeyemi, I. A. 2003. Effect of Processing Factors on Rheological Properties of Ogi. International journal of food properties, 6 (3): 405-418.

[6] Osundahunsi, O. F. and Aworh, O. C. 2003. Nutritional Evaluation with Emphasis on Protein Quality of Maize-Based Complementary Foods Enriched with Soya Bean and Cowpea Tempe. International Journal of Food Science and Technology, 38: 809-813.

[7] Akingbala, J. O., Akinwande, B. A. and Uzo-Peters, P. I. 2005. Effects of Color and Flavor Changes on Acceptability of $O g i$ Supplemented with Okro Seed Meals. Plant Foods for Human Nutrition, 58 (3): 1-9.

[8] Egounlety, M., Aworh, O. C., Akingbala, J. O., Houben, J. H. and Nago, M. C. 2002. Nutritional and Sensory Evaluation of Tempe-Fortified Maize-Based Weaning Foods. International Journal of Food Sciences and Nutrition, 53: 15-27.

[9] Nnam, N. M. 2000. Chemical Evaluation of Multi-mixes Formulated from some Local Staples for use as Complementary Food in Nigeria. Plant Foods for Human Nutrition, 55 (3): 255-263.

[10] Ajanaku, K. O., Ajanaku, C. O., Edobor-Osoh, A. and Nwinyi O. C. 2013. Nutritive Value of Sorghum Ogi Fortified with Groundnut Seed (Arachis hypogaeaL.)", American Journal of Food Technology, 7: 82-88.

[11] Iombor, T. T., Umoh, E. J. and Olakumi, E. 2009. Proximate Composition and Organoleptic Properties of Complementary Food Formulated from Millet (Pennisetum psychostachynum), Soybeans (Glycine max) and Crayfish (Euastacus spp) Pakistan Journal of Nutrition, 8 (10): 1676-1679.

[12] Smith, P. G. 2003. Introduction of Food Process Engineering. Kluwer Academy/Plenum Publications, New York; pp. 47-72. 
[13] PAG. 1971. Guidelines on Protein Rich Mixtures for use in Weaning Foods. Protein Advisory Group, United Nations, New York.

[14] AOAC 2005. Official Methods of Analysis: 18th Edition. Association of Official Analytical Chemists. Washington, DC. pp. 210 .

[15] Ihekoronye, A. I. and Ngoddy, P. O. 1985. Integrated Food Science and Technology for the Tropics, 1st Edn., Macmillian Publishers Ltd. London.

[16] Woldegiorgis, A. Z., Abate, D., Haki, G. D. and Ziegler, G. R. 2015. Major, Minor and Toxic Minerals and Anti-nutrients Composition in Edible Mushrooms Collected from Ethiopia. Food Processing Technology. 6:134-142.

[17] Iwe, M. O. 2002. Handbook of Sensory Analysis and Methods. Projoint Communications Services Ltd., Enugu. pp 70-72.

[18] Sengev, I. A., Akpapunam, M. A. and Ingbian, E. K. 2012. Physicochemical and Sensory Properties of Instant Kununzaki Flour Blends from Sorghum and Mango Mesocarp Flours. Nigerian Food Journal, 30 (2): 8-12.

[19] FAO/WHO 1991. Protein Quality Evaluation Report of Joint FAO/WHO Expert Consultative FAO Food and Nutrient. FAO, Rome, Italy.

[20] Ijarotimi, S. O. and Keshinro, O. O. 2013. Determination of Nutrient Composition and Protein Quality of Potential Complementary Foods Formulated from the Combination of Fermented Popcorn, African Locust and Bambara Groundnut Seed Flour. Polish Journal of Food and Nutrition Sciences, 63 (3): $155-166$.

[21] Ross, S. A., McCaffery, P. J., Drager, U. C. and De Luca, L. M 2000. Retinoids in Embryonal Development. Physiological Reviews, 80: 1021-54.

[22] Fattal-Valevski, A. 2011. "Thiamin (vitamin B B)". Journal of Evidence-Based Complementary and Alternative Medicine, 16 (1): 12-20.

[23] University of Bristol 2002. "Vitamin B12". Retrieved 16 September 2012.

[24] Solomon, M. 2005. Nutritive Value of Three Potential Complementary Foods Based on Cereals and Legumes. African Journal of Food and Nutritional Sciences: 5 (2): 1-14.

[25] Okaka, J. C. and Okaka, A. N. O. 2001. Food composition, spoilage and shelf life extension, ocjarco Acadamic Publishers, Enugu, Nigeria, pp: 54-56.

[26] EFSA NDA Panel 2014. European Food Safety Authority Panel on Dietetic Products Nutrition and Allergies. Scientific Opinion on Dietary Reference Values for iodine. EFSA Journal, 12 (5): 57.

[27] Ullah, R. J. A., Khader, I., Hussain, N. M., Talha, A. M. and Khan, N. 2012. Investigation of Macro and Micronutrients in
Selected Medicinal Plants. African Journal of Pharmacy and Pharmacology, 69: 1829-1832.

[28] Jabeen, S., Shah, M. T., Khan, S. and Hayat, M. Q. 2010. The Typical Symptoms of Determination of Major and Trace Elements in Ten Important Folk Therapeutic Plants of Haripur Basin. Journal of Medicinal Plants, 4: 559-566.

[29] Arinathan, V., Mohan V. R. and John De Britto, A. 2003. Chemical Composition of Certain Tribal Pulses in South India. International Journal of Food Sciences and Nutrition, 54: 209-217.

[30] Mlitan, A. M., Sasi, M. S. and Alkherraz, A. M. 2014. Proximate and Minor Mineral Content in some Selected Basil Leaves of Ocimum gratissimum $L$ in Libya. International Journal of Chemical Engineering and Applications. 5:8-17.

[31] Oke, O. L. 1969. Chemical studies on the more commonly used vegetables in Nigeria. Afr. Sci. Ass. 11: 42-48.

[32] Erdman, J. N. 1979. Oily seed phytates nutritional implications. Journal of the American Oil Chemists' Society, 56: 736-741.

[33] Reed, J. D. 1995. Nutritional Toxicology of Tannins and Related Polyphenols in Forage Legumes. Journal of Animal Science, 73 (5): 1516-28.

[34] Folake, O. S., Oluwaseun, R. I. and Bolanle, O. O. 2015. Nutritional and Sensory Evaluation of Rice Based Masa Enriched with Soybean and Crayfish. Food and Nutrition Sciences, 6: 234-241

[35] Omoruyi, F. O., Dilworth, L. and Asemota, H. N. 2007. Antinutritional factors, Iron and Calcium in some caribbean tuber crops and the effect of boiling or roasting. Nutrition and Food Science, 37: 8 - 15 .

[36] Bhandari M.R. and Kawabata J. 2004. Assessment of Antinutritional Factors and Bioavailability of calcium and in wild yam (Dioscorea spp.) tubers of Nepal. Food Chemistry 85: 281-287.

[37] Woldegiorgis, A. Z., Abate D., Haki G. D., Ziegler, G. R. 2014 Antioxidant property of edible mushrooms collected from Ethiopia. Journal of Food Chemistry, 157: 30-36.

[38] Obah, G. and Amusan, T. V. 2009. Nutritive Value and Antioxidant Properties of Cereal Gruels Produced from Fermented Maize and Sorghum. Journal of Food Biotechnology 23: 17- 31 .

[39] Morris, E. R. and Ellis, R. 1989. Usefulness of the Dietary phytIc acid/zinc molar ratio as an Index of Zinc Bioavailability to Rats and Humans. Biological Trace Element Research, 19: 107-117.

[40] Melaku, U., West, C. E. and Habtamu, F. 2005. Content of, iron, calcium and their absorption inhibitors in foods commonly consumed in Ethiopia. Journal of Food Composition and Analysis, 18: 803-817. 